\title{
Antioxidant and Antihypertensive Activity of Collagen and Elastin Hydrolysate at Different Molecular Weights
}

\author{
Bayarjargal Munkhuu ${ }^{1} *$, Lkhagvamaa Erdene ${ }^{1}$, Zolzaya Bayarsukh ${ }^{1}$, \\ Enkh-Ariun Altantulga ${ }^{1}$, Oyuntuya Baltsukh ${ }^{1}$, Gan-Erdene Tudev ${ }^{1}$,
}

Ariun Narmandakh ${ }^{2}$

${ }^{1}$ Institute of Chemistry and Chemical Technology, Mongolian Academy of Sciences, Peace Avenue, Ulaanbaatar 13330, Mongolia

${ }^{2}$ School of Physics, Engineering and Computer Science, University of Hertfordshire, Hatfield, Hertfordshire, AL $109 A B$, United Kingdom

*Corresponding author. Email: bayarjargalm@mas.ac.mn

\begin{abstract}
The angiotensin-converting enzyme (ACE) inhibitory activity and antioxidant property of collagen and elastin hydrolysates, and their peptide fractions $(<5 \mathrm{kDa}, 5-10 \mathrm{kDa}, 10-100 \mathrm{kDa})$ were compared. The bovine raw-hide and paddywhack (Ligamentum nuchae) were used for the preparation of collagen and elastin hydrolysates, respectively. Unfractionated collagen and elastin hydrolysates $(4 \mathrm{mg} / \mathrm{mL})$ could reduce ACE activity by $61 \%$ and $58 \%$. As a result of fractionation, ACE inhibitory activity of collagen hydrolysate was increased up to $85 \%$, while this effect was not observed on elastin hydrolysate. Elastin hydrolysate showed intense radical scavenging abilities through 2,2-diphenyl-1-picrylhydrazyl (DPPH) and 2,2'-Azinobis-(3-Ethylbenzthiazolin-6-Sulfonic Acid (ABTS) assay. The collagen hydrolysate obtained from the bovine rawhide has more perspective for the bioactive food additive having ACEI activity in comparison with the elastin hydrolysate.
\end{abstract}

Keywords: Raw-hide, Ligamentum nuchae, Hydrolysate, Ultrafiltration, Peptides, Angiotensinconverting enzyme inhibitor, Antioxidant activity

\section{INTRODUCTION}

Collagen and elastin are abundant proteins in the body that play an impotent role in human and animal connective tissue processes $[1,2]$.

Collagen gives tissue mechanical strength, while elastin provides elasticity and plays a significant role in tissue development [3]. Only a few tissues, such as ligament and blood vessels are rich in elastin [4]. The average elastin content observed in cattle and horse Ligamentum nuchae (yellow ligament or paddywhack) was up to $70 \%$ in contrast to the skin [5].
After enzymatic breakdown collagen and elastin form low molecular peptides, which are rapidly absorbed from the gastrointestinal tract and may act as signalling molecules, thereby stimulating anabolic processes in the organism $[2,3,6]$. The peptides with low molecular weight originated from collagen and elastin reveal the high biological activity [7, 8]. Many bioactive peptides demonstrate multifunctional activity [9].

Hydrolyzed collagen from fish, poultry, animal skin, and/or their peptide fractions obtained by the ultrafiltration process was considered to be an antioxidant $[10,11]$ as well as a potential substance with beneficial effects on hypertension and 
thrombosis [1, 12]. Bovine collagen is a promising precursor of ACE inhibitory peptides due to the high occurrence of bioactive motifs encrypted in its sequences [9, 12]. High amounts of Gly and Pro residues play an important role in the biological activity of collagen [12]. Pro-Gly dipeptide originated from Skipjack-elastin hydrolysate enhances the elastin synthesis by human dermal fibroblast and the growth of human umbilical vein endothelial cells [3]. The biological activity of released peptides depends on the enzyme specificity and proteolysis conditions $[12,13]$. The findings of animal experiments and placebo-controlled human trials demonstrate that oral supplementation of collagen hydrolysis products had a favourable effect on increasing bone mineral density, bone marker in blood [6], in the treatment of osteoarthritis and osteoporosis [14], skin aging $[15,16]$.

The ultrafiltration process is widely used for the production of protein hydrolysates with high biological activity and containing relatively small molecular weight peptides. We have expected that peptide fractions having a molecular weight lower than $10 \mathrm{kDa}$ will show better activity.

Therefore, the aim of this research is to examine some physicochemical properties of pancreatic hydrolysates of collagen and elastin obtained from bovine raw-hide and paddywhack and elucidate the ACE inhibitory activity (ACEI), radical scavenging activity of prepared hydrolysates at the different molecular weight (<5 kDa, 5-10 kDa, 10-100 kDa).

\section{EXPERIMENTAL}

\subsection{Materials}

Bovine rawhide and paddywhack (Ligamentum nuchae) were bought from the local market Emeelt, Ulaanbaatar. The hippuryl-1-histidyl-1-leucine (HHL), ACE from rabbit lung, DPPH, and ABTS were purchased from Sigma-Aldrich, Germany. All chemicals used were of analytical grade.

\subsection{Preparation of Collagen $(\mathrm{CH})$ and Elastin (EH) Hydrolysates and Their Fractions}

Bovine rawhide and paddywhack were swelled in an alkaline solution and then neutralized in an acidic solution. After this procedure, materials were chopped and hydrolyzed using fresh bovine pancreatic tissue. The hydrolysis of bovine hide and paddywhack substrates were conducted in the same conditions at $\mathrm{pH} 7.5-8.0,50^{\circ} \mathrm{C}$ degrees for $5 \mathrm{~h}$. The
E:S ratio was 1:4. Collagen and elastin hydrolysates obtained from bovine rawhide and paddywhack respectively were fractionated by using Amicon stirred ultrafiltration membrane with molecular weight cut-off sizes 100, 10, $5 \mathrm{kDa}$ (Millipore, USA). All fractions were freeze-dried and used for further analysis.

\subsection{Determination of Total and Amino Nitrogen}

The amount of total nitrogen (TN) in protein hydrolysates was determined using the Kjeldahl semi-automatic system as described in European Pharmacopoeia [17]. The amine nitrogen (AN) content was determined by the formol titration method, according to U.S.Pharmacopoeia [18]. The AN/TN was calculated for hydrolysates and used for the assessment of the degree of hydrolysis.

\subsection{Nitrogen Solubility of Collagen and Elastin Hydrolysates}

The nitrogen solubility index was determined using the method described by Morr et al. with some modification [19]. About $2.000 \mathrm{~g}$ of hydrolysate was dispersed in $75 \mathrm{~mL}$ of distilled water, and $\mathrm{pH}$ was adjusted to $\mathrm{pH} 7.0$ using $0.1 \mathrm{M} \mathrm{HCl}$. The $\mathrm{pH}$ was readjusted to 7.0 after stirring at room temperature for $1 \mathrm{~h}$. The mixture was diluted with distilled water to $100 \mathrm{~mL}$ in a volumetric flask and mixed thoroughly. A suitable portion of the mixture was analyzed immediately using the Kjeldahl method [17]. The remaining mixture was allowed to stand for $2 \mathrm{~min}, 35 \mathrm{~mL}$ of the hydrolysate solution was centrifuged at $3000 \mathrm{rpm}$ for $30 \mathrm{~min}$. The supernatant was filtered through Whatman filter paper No.1 and nitrogen content was analyzed using the Kjeldahl method [17]. The nitrogen solubility index (NSI) was calculated using Equation (1).

$\operatorname{NSI}(\%)=\frac{N_{s}}{N_{d}} \times 100$

where $N_{s}-$ nitrogen content of supernatant; $N_{d}-$ nitrogen content of the dispersion

\subsection{Spectrophotometric Method for the Determination of Hydroxyproline}

The sample was hydrolyzed in $\mathrm{H}_{2} \mathrm{SO}_{4}$ at $105^{\circ} \mathrm{C}$, filtered, and diluted. Hydroxyproline is oxidized with chloramine-T to pyrrole. Red-purple color that develops after the addition of 4dimethylaminobenzaldehyde is measured at $560 \mathrm{~nm}$ [20]. 


\subsection{Angiotensin-Converting Enzyme (ACE) Activity of Fractionated Collagen (CH) and Elastin (EH) Hydrolysate}

ACE inhibitory activity was assayed according to the method described by Cushman.D.W with some modifications [21]. For each assay, $65 \mu \mathrm{L}(4 \mathrm{mg} / \mathrm{mL})$ of a sample solution, inhibitor $(1 \mathrm{mg} / \mathrm{mL})$ with $10 \mu \mathrm{L}$ of ACE solution ( $2 \mathrm{mU}$ ) in sodium borate buffer was pre-incubated at $37^{\circ} \mathrm{C}$ for $10 \mathrm{~min}$. About $50 \mu \mathrm{L}$ of substrate (HHL) solution (12.5 mM HHL in $0.1 \mathrm{M}$ sodium borate buffer containing $0.5 \mathrm{M} \mathrm{NaCl}$ at $\mathrm{pH}$ 8.3) was added to the above mixture and incubated for $1 \mathrm{~h}$ at $37^{\circ} \mathrm{C}$. The reaction was terminated by the addition of $125 \mu \mathrm{L}$ of $0.5 \mathrm{M} \mathrm{HCl}$. To the resulting solution, $750 \mu \mathrm{L}$ of ethyl acetate was added and centrifuged at $2500 \mathrm{rpm}$ for $10 \mathrm{~min}$ to extract the hippuric acid (HA) in the ethyl acetate layer. After that $200 \mu \mathrm{L}$ of the upper ethyl acetate layer was transferred into a test tube, and oven-dried $\left(80^{\circ} \mathrm{C}\right)$. The HA was dissolved in $1.0 \mathrm{~mL}$ of Milli $\mathrm{Q}$ water and the absorbance of this solution was measured at $228 \mathrm{~nm}$ using a UV-spectrophotometer (Shimadzu UVmini-1240, Japan). The amount of HA liberated from $\mathrm{HHL}$ in the absence of an inhibitor was taken as control (100\% ACE inhibition activity). Milli Q water was used as a blank for each sample. Each sample was performed in triplicate. The percentage inhibition of ACE was calculated by Equation (2).

$A C E I$ activity $(\%)=\frac{A-B}{A-C} \times 100$

where $\mathrm{A}$ is the optical density at $228 \mathrm{~nm}$ with ACE but without an inhibitor. $\mathrm{B}$ is the optical density in the presence of both ACE and inhibitor. $\mathrm{C}$ is the optical density without ACE and inhibitor.

\subsection{ABTS Radical Scavenging Activities of Fractionated Collagen ( $\mathrm{CH})$ and Elastin Hydrolysate (EH)}

ABTS radical scavenging activity was determined according to $R e R$., et al. with some modifications [22]. An ABTS solution (1.7 $\mathrm{mM}$ in water) is mixed in the ratio $5: 1$ with potassium persulfate solution (4.3 $\mathrm{mM}$ in water) and incubated for $12-16 \mathrm{~h}$ at room temperature in the dark. Immediately before measurement, this stock solution is diluted with PBS buffer ( $\mathrm{pH} 7.4)$ to an extinction value of $0.700 \pm 0.020$ at $734 \mathrm{~nm}$. After the addition of $1.0 \mathrm{~mL}$ diluted ABTS solution to $10 \mu \mathrm{L}$ sample mixed and extinction at $734 \mathrm{~nm}$ is measured after exactly 6 min against the buffer. The percentage of ABTS radical scavenging activity was calculated by Equation (3). ABTS radical scavenging activity. $\%=$
$\frac{\text { Absorbance control } \text { Absorbance sampls }_{\text {shorbance }}}{\text { Absolvol }} \times 100$

\subsection{DPPH Radical Scavenging Activities of Fractionated Collagen (CH) and Elastin Hydrolysate (EH)}

The DPPH radical scavenging activity was determined as described by Brand-Williams W., et al. [23]. The stock solution of DPPH was prepared daily by dissolving $40 \mathrm{mg}$ of DPPH in $100 \mathrm{~mL}$ of $95 \%$ ethanol. The working solution of DPPH having an extinction value of $0.85-1.00$ at $517 \mathrm{~nm}$ was prepared by diluting of stock solution of DPPH. To the analyzed sample $(1.5 \mathrm{~mL})$, a working solution of DPPH $(1.5 \mathrm{~mL})$ is added. The mixture was vigorously mixed and incubated at room temperature in a dark place for $30 \mathrm{~min}$. The absorbance of the resulting solution was measured at $517 \mathrm{~nm}$. The blank contained distilled water instead of a sample. The ability to scavenge the DPPH radicals has been determined using the following Equation (4).

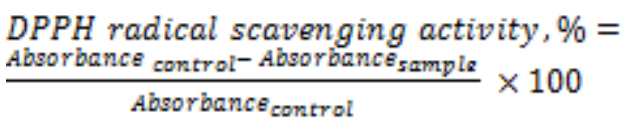

\subsection{Statistical Analysis}

All experiments were conducted in triplicate. The mean values \pm standard deviation were calculated. Statistical analysis was performed using ANOVA and mean comparisons were evaluated at a $95 \%$ confidence level.

\section{RESULTS AND DISCUSSION}

Some physicochemical properties of collagen $(\mathrm{CH})$ and elastin $(\mathrm{EH})$ hydrolysates obtained from bovine raw-hide and paddywhack, respectively are shown in Table 1.

Table 1. Functional properties of collagen and elastin hydrolysate

\begin{tabular}{|l|l|l|}
\hline $\begin{array}{l}\text { Functional } \\
\text { properties }\end{array}$ & $\begin{array}{l}\text { Collagen } \\
\text { hydrolysate }\end{array}$ & $\begin{array}{l}\text { Elastin } \\
\text { hydrolysate }\end{array}$ \\
\hline Crude protein, \% & $85.2 \pm 1.0$ & $79.4 \pm 1.7$ \\
\hline AN/TN & $0.18 \pm 0.2$ & $0.23 \pm 0.2$ \\
\hline $\begin{array}{l}\text { Hydroxyproline } \\
\text { (collagen), \% }\end{array}$ & $\begin{array}{l}10.2 \pm 0.2 \\
(76)\end{array}$ & $\begin{array}{l}2.8 \pm 0.2 \\
(21)\end{array}$ \\
\hline NSI, \% & 96 & 100 \\
\hline
\end{tabular}


The hydroxyproline content is the main characteristic of collagen products. The collagen concentration may be estimated from the hydroxyproline content of the substance through multiplication by the factor 7.46 [24]. Two hydrolysates had a drastic difference in collagen concentration.

The hydroxyproline content of hydrolysate obtained from bovine paddywhack was only $2.8 \%$ versus $10.2 \%$ of hydrolysate derived from bovine raw-hide. But this results in agreement with the collagen percentage in Ligamentum nuchae which is found in the amount of $17 \%$.

The collagen content of the skin is about $90 \%$ of the total protein. In this key $89 \%$ of the crude protein of hydrolysate obtained from bovine raw-hide originated from collagen. The degree of hydrolysis reveals a measure of the extent of hydrolytic degradation of proteins, or percent of peptide bonds cleaved, and expresses the ratio of amino nitrogen to total nitrogen (AN/TN) [25]. This parameter affects the size of peptide chains in hydrolysate and its solubility. Despite low AN/TN ratio $\mathrm{CH}$ and $\mathrm{EH}$ had high solubility and nitrogen solubility index (Table 1). This expands the possibility of good separation by ultrafiltration technique as well as the suggestion for use in a variety of products, including food, feed, and cosmetics.
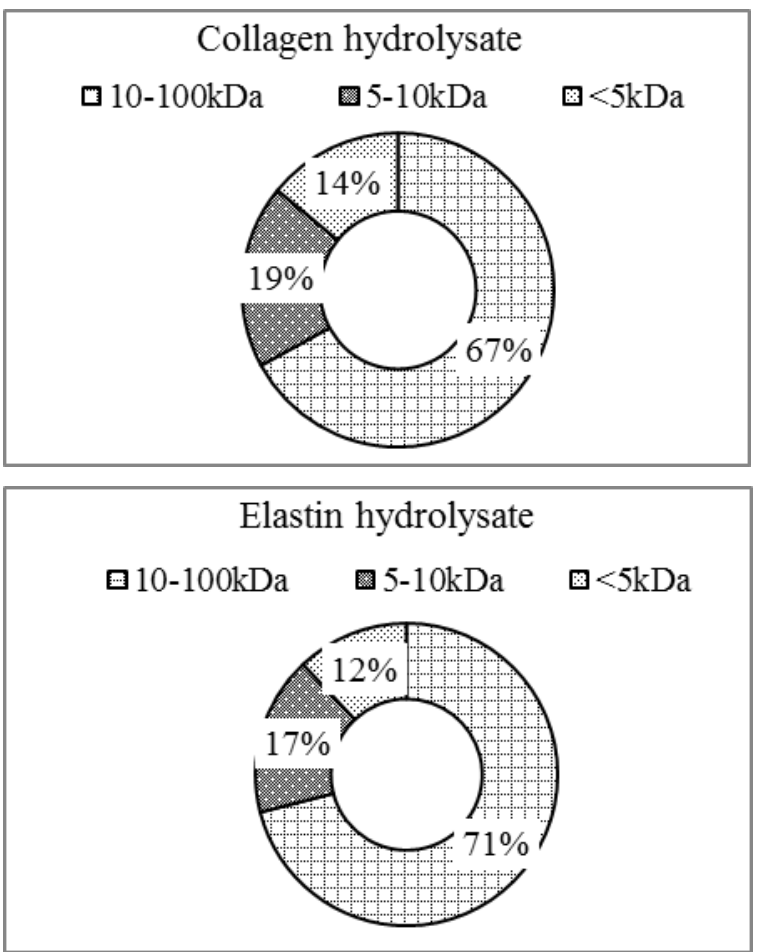

Figure 1. The yield of peptide fractions isolated by ultrafiltration membrane
Each of the analyzed hydrolysates was fractionated into three fractions by ultrafiltration membranes. The yield of peptide fractions and ACE inhibitor activity, antioxidant properties were compared. The yield of isolated 10-100, 5-10, $<5 \mathrm{kDa}$ peptide fractions referred to as $\mathrm{CH}$ and $\mathrm{EH}$ are shown in Figure 1.

The yield of peptide fractions with a molecular weight of $10-100 \mathrm{kDa}$ in $\mathrm{CH}$ and $\mathrm{EH}$ was relatively high (67\% and $71 \%$ ). This may cause by the low $\mathrm{AN} / \mathrm{TN}$ ratio of estimated hydrolysates.

The fractionation of $\mathrm{CH}$ and $\mathrm{EH}$ using ultrafiltration showed opposite effects (Figure 2). This procedure led to an increase of ACE inhibitor activity of $\mathrm{CH}$, while the activity of $\mathrm{EH}$ was decreased. The commercial ACEI $(1 \mathrm{mg} / \mathrm{mL})$ was used as a control and showed the highest (89.4\%) activity. The isolated peptide fractions of $\mathrm{CH}$ demonstrated higher ACE inhibitory activity than those exhibited by untreated $\mathrm{CH}$. 10-100 kDa and $<5$ $\mathrm{kDa}$ fractions of $\mathrm{CH}$ expressed the highest ACE inhibitory activity compared to other fractions observed. The results demonstrated that the antihypertensive activity of $\mathrm{CH}$ fractions with $10-100$ $\mathrm{kDa}(\mathrm{p}$-value $=0.267)$ and $<5 \mathrm{kDa}(\mathrm{p}$-value $=0.206)$ were not statistically different from the commercial inhibitor, and the other fractions were significantly different ( $\mathrm{p}$-value $<0.05)$.

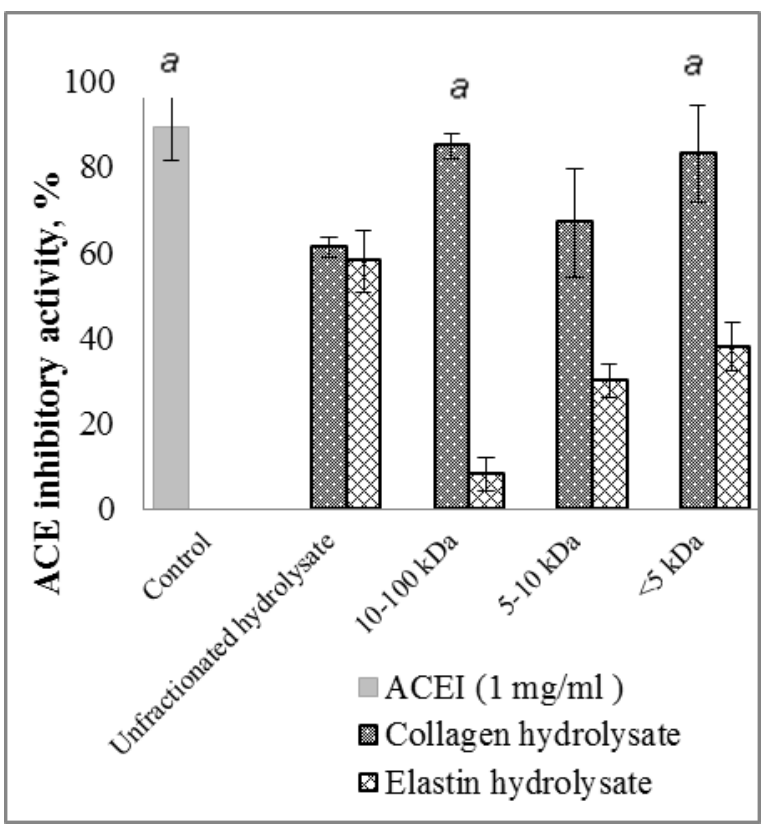

Figure 2. ACE inhibitory activity of collagen and elastin hydrolysates in comparison with their peptide fractions obtained by ultrafiltration (Value with the same superscript letter (a) indicates no significant difference $(p>0.05))$ 
In recent years the use of antioxidants in the diet of people increased significantly. A popular ingredient considered an antioxidant is a collagen in its hydrolyzed form. The antioxidant activity of collagen hydrolysis products has a significant role when used in cosmetics products due to the scavenging free radicals produced under UV light and negative environmental conditions. There is no information showed that molecular size associate with antioxidant activity. But peptides from 500-3000 Da molecular weight peptide tend to have high antioxidant activity $[8,25]$.

The antioxidant activity of fractionated hydrolysates at different molecular weights was determined at the same concentration $(4 \mathrm{mg} / \mathrm{mL})$ used for ACEI assay. The results were expressed as $\mathrm{IC}_{50}$ concentration, where $50 \%$ of scavenging of the ABTS cation radical and DPPH free radical (Table 2).

Table 2. Antioxidant activities of fractionated collagen and elastin hydrolysates

\begin{tabular}{|c|c|c|}
\hline \multirow{2}{*}{ Samples } & \multicolumn{2}{|c|}{$\mathrm{IC}_{50}(\mathrm{mg} / \mathrm{mL})$} \\
\hline & ABTS & DPPH \\
\hline $\begin{array}{l}\text { Collagen } \\
\text { hydrolysate }\end{array}$ & $5.2 \pm 0.6$ & $38.0 \pm 4.8$ \\
\hline 10-100 kDa & $8.1 \pm 0.8$ & $15.1 \pm 4.8$ \\
\hline 5-10 kDa & $6.1 \pm 0.6$ & $25.1 \pm 4.2$ \\
\hline$\leq 5 \mathrm{kDa}$ & $5.2 \pm 0.7$ & $39.0 \pm 3.9$ \\
\hline $\begin{array}{l}\text { Elastin } \\
\text { hydrolysate }\end{array}$ & $3.6 \pm 0.7$ & $12.2 \pm 2.9$ \\
\hline 10-100 kDa & $3.8 \pm 0.5$ & $6.1 \pm 1.3$ \\
\hline 5-10 kDa & $3.5 \pm 0.3$ & $17.7 \pm 4.5$ \\
\hline$\leq 5 \mathrm{kDa}$ & $2.7 \pm 0.4$ & $17.6 \pm 2.4$ \\
\hline $\begin{array}{l}\text { Glutathione } \\
\text { (Sigma Aldrich) }\end{array}$ & $0.4 \pm 0.1$ & $0.07 \pm 0.01$ \\
\hline
\end{tabular}

The peptide fraction of EH with $\mathrm{MW} \leq 5 \mathrm{kDa}$ exhibited the highest ABTS radical scavenging activity, followed by fractions with MW 5-10 kDa, and MW 10-100 kDa. If fractionation of $\mathrm{EH}$ was influenced on ABTS cation radical scavenging activity, while it was not observed on $\mathrm{CH}$. EH's peptide fraction with MW 10-100 kDa shows the highest DPPH radical scavenging activity (6.1 $\mathrm{mg} / \mathrm{mL} \mathrm{IC}_{50}$ ), which was significantly higher than that of other examined samples. $\mathrm{CH}$ and its peptide fractions have lower activity on DPPH radical scavenging in comparison with EH. This unfractionated collagen hydrolysate and peptide fraction with $\mathrm{MW} \leq 5 \mathrm{kDa}$ showed very low $\mathrm{DPPH}$ radical scavenging activity. These results show the importance of the research on the peptide composition and activity relation.

DPPH activity of collagen and elastin peptide fractions differences were analyzed by a one-way ANOVA test. Both peptide fractions were statistically different within groups (p-value $($ collagen $)=0.000137 ; \mathrm{p}$-value $($ elastin $)=0.004)$. Oneway ANOVA test was applied to comparing ABTS radical scavenging activity within elastin and collagen fractions. The results showed that collagen $(p$-value $=0.000005)$ and elastin $(p$-value $=0.000004)$ peptide fractions were statistically significant.

\section{CONCLUSION}

The antihypertensive activity of bovine raw-hide and paddywhack hydrolysates after fractionation by ultrafiltration procedure was increased for collagen hydrolysate and decreased for elastin hydrolysate. Fractionation of elastin hydrolysate leads to an increase in antioxidant activity. The expectation was not realized for both biological activity and the ultrafiltration process leads to enhance of the ACEI activity up to 1.4 times for collagen hydrolysate only. We concluded that the production of collagen hydrolysate has more perspective for the bioactive food additive having ACEI activity in comparison with the elastin hydrolysate.

\section{ACKNOWLEDGMENTS}

This research was supported by the Mongolian Foundation of Science and Technology, funded by the Ministry of Education, Culture, Science and, Sports of Mongolia (Project No ShuSs-2018/13).

\section{REFERENCES}

[1] Miranda N.D., Chaikof E.L., (2017) Collagen and Elastin Biomaterials for the Fabrication of Engineered Living Tissues. ACS Biomaterials . Science and Engineering. Vol. 3(5), 694-711. DOI: $10.1021 /$ acsbiomaterials.6b00250.

[2] Wang L., Wang Q., Qian J., Liang Q., Wang Z., Xu J., He S., Ma H., (2015) Bioavailability and Bioavailable Forms of Collagen after Oral Administration to Rats. Journal of Agricultural and Food Chemistry. Vol. 63(14), 3752-3756.

[3] Shiratsuchi E., Nakaba M., Shigemura Y., Yamada M., Sato K., (2013) Fish-elastin 
Hydrolysate: Development and Impact on the Skin and Blood vessels. In Marine Proteins and Peptides: Biological Activities and applications. First ed. Wiley \& Sons, 467-486.

[4] John R., Thomas J., (1970) Localization and chemical composition of elastin in ox lung. Biochemical. Journal, Vol. 118(3), 58. DOI: 10.1042/bj1180058P.

[5] Meyer M., (2019) Processing of collagen based biomaterials and the resulting materials properties. Biomedical Engineering Online, Vol. 18, 24. DOI: 10.1186/s12938-019-0647-0

[6] Koenig D., Oesser S., Scharla S., Zdzieblik D., Gollhofer A., (2018) Specific Collagen Peptides Improve Bone Mineral Density and Bone Markers in Postmenopausal Women-A Randomized Controlled Study. Nutrients, Vol. 10, 97. DOI: $10.3390 /$ nu10010097

[7] Guillerminet F., Beaupied H., Fabien-Soule V., Tome D., Benhamou C.L., Roux C., Blais A., (2010) Hydrolyzed collagen improves bone metabolism and biomechanical parameters in ovariectomized mice: an in vitro and in vivo study. Bone, Vol. 46, 827-834. DOI: 10.1016/j.bone.2009.10.035

[8] Razali A.N., Amin A.M., Sarbon N.M., (2015) Antioxidant activity and functional properties of fractionated cobia skin gelatin hydrolysate at different molecular weight. International food Research Journal, Vol. 22, 651-660.

[9] Minkiewicz P., Dziuba J., Michalka J., (2011) Bovine meat proteins as potential precursors of biologically active peptides - a computational study based on the BIOPEP database. Food Science and Technology International. Vol. 17, 39-45. DOI: 10.1177/1082013210368461

[10] Shaik M.I., Noor A.N.A.A.M., Sarbon N.M., (2021) In-vitro angiotensin converting enzyme (ACE), antioxidant activity and some functional properties of silver catfish (Pangasius sp.) protein hydrolysate by ultrafiltration. Biocatalysis and Agricultural Biotechnology. Vol. $\quad 35, \quad 102100 . \quad$ DOI: 10.1016/j.bcab.2021.102100

[11] Gomez-Guillen M.C., Gimenz B., LopezCaballeo M.E., Montero M.P., (2011) Functional and bioactive properties of collagen and gelatin from alternative sources: A review. Food Hydrocolloid. Vol. 25, 1813-1827. DOI: 10.1016/j.foodhyd.2011.02.007
[12] Fu Y., Young J.F., Lokke M.M., Lametsch R., Aluko R.E., Therkildsen M., (2016) Revalorisation of bovine collagen as a potential precursor of angiotensin I-converting enzyme (ACE) inhibitory peptides based on in silico and in vitro protein digestions. Journal of Functional Foods. Vol. 24, 169-206. DOI: 10.1016/j.jff.2016.03.026

[13] Hong G.P., Min S.G., Jo Y.J., (2019) AntiOxidative and Anti-Aging Activities of Porcine by-Product Collagen Hydrolysates Produced by Commercial Proteases: Effect of Hydrolysis and Ultrafiltration. Molecules. Vol. 24(6), 1104. Vol. 10. DOI: 3390/molecules24061104

[14] Moskowitz R.W., (2000). Role of collagen hydrolysate in bone and joint disease. Seminars in Arthritis and Rheumatism. Vol. 30(2), 87-99. DOI: $10.1053 /$ sarh.2000.9622.

[15] Proksch E., Segger D., Degwert J., Schunck M., Zague V., Oesser S., (2014) Oral supplementation of specific collagen peptides has beneficial effects on human skin physiology: a double-blind, placebo controlled study. Skin Pharmacology and Physiology. Vol. 27(1), 47-55. DOI: 10.1159/000351376

[16] Asserin J., Lati E., Shioya T., Prawitt J., (2015) The effect of oral collagen peptide supplementation on skin moisture and the dermal collagen network: evidence from an ex vivo model and randomized, placebo-controlled clinical trials. Journal of Cosmetic Dermatology, Vol. 14(4), 291-301. DOI: 10.1111/jocd.12174

[17] European Pharmacopoeia., (2010) Council of Europe, 7th Ed., Methods of analysis, 139.

[18] The United States Pharmacopoeia (USP) XXIX. The National Formulary (NF) XXIV. Protein hydrolysate injection, 1854.

[19] Morr C.V., German B., Kinsella J.E., Regenstein J.M., Van Buren. J.P., et al., (1985) A Collaborative Study to Develop a Standardized Food Protein Solubility Procedure. Journal of Food Science, Vol.50, 1715-1718. DOI: 10.1111/j.1365-2621.1985.tb10572

[20] Association of Official Analytical Chemists. (1990). Official methods of Analysis (Patricia A.Cunniff, Ed.; 16th ed., Vol. 2). AOAC international, Ch39, 13-15.

[21] Joel C.H., Sutopo C.C.Y., Prajitno A., Su J.H., Hsu J.L., (2018) Screening of Angiotensin-I 
Converting Enzyme Inhibitory Peptides Derived from Caulerpa lentillifera. Molecules. Vol. 23(11), $3005 . \quad$ DOI: 10.3390/molecules23113005

[22] Re R., Pellegrini N., Proteggente A., Pannala A., Yang M., et al., (1999) Antioxidant activity applying an improved ABTS radical cation decolorization assay. Free Radical Biology and Medicine, Vol. 26, 1231-1237. DOI: /10.1016/S0891-5849(98)00315-3

[23] Brand-Williams W., Cuvelier M.E., Berset C., (1995) Use of a free radical method to evaluate antioxidant activity. LWT-Food Science and Technology Vol. 28(1), 25-30. DOI: 10.1016/S0023-6438(95)80008-5

[24] Ju H., Zhao S., Jassal D.S., Dixon I.M.C., (1997) Effect of AT receptor blockade on cardiac collagen remodeling after 1 myocardial infarction. Cardiovascular Research. Vol. 35, 223-232. DOI: 10.1016/s0008-6363(97)00130-2

[25] Wang X., Yu H., Xing R., Chen X., Liu S., Li P., (2017) Optimization of antioxidative peptides from mackerel (Pneumatophorus japonicus) viscera. Peer Journal. DOI: $10.7717 /$ peerj. 4373 